\title{
Comparative phylogenetic analyses of members of the order Planctomycetales and the division Verrucomicrobia: 235 rRNA gene sequence analysis supports the 16S rRNA gene sequence-derived phylogeny
}

\author{
Naomi L. Ward, ${ }^{1,2}$ Fred A. Rainey, ${ }^{1,2}$ Brian P. Hedlund, ${ }^{3}$ James T. Staley, ${ }^{3}$ \\ Wolfgang Ludwig ${ }^{4}$ and Erko Stackebrandt ${ }^{1}$
}

Author for correspondence: Naomi L. Ward. Tel: +1 225388 1506. Fax: +1 2253882597.

\footnotetext{
1 Deutsche Sammlung von Mikroorganismen und Zellkulturen $\mathrm{GmbH}$, Braunschweig, Germany

2 Department of Biological Sciences, 508 Life Sciences Building, Louisiana State University, Baton Rouge, LA 70803, USA

3 Department of Microbiology, University of Washington, Seattle, Washington, USA

4 Lehrstuhl für Mikrobiologie, Technische Universität München, München, Germany
}

\begin{abstract}
Almost complete 23S rRNA gene sequences were obtained from 13 planctomycete strains, the fimbriated, prosthecate bacterium Verrucomicrobium spinosum and two strains of the genus Prosthecobacter. The 235 rRNA genes were amplified by the PCR, using modified primers. The majority of the planctomycete strains investigated were shown to have 235 rRNA genes that were not linked to the 16S rRNA genes. Amplification of the 5'-termini of these genes was achieved using a novel primer-design strategy. Comparative phylogenetic analyses were performed using the 235 rRNA gene sequences determined in this study and previously determined 16S rRNA gene sequences. The phylogenetic dendrograms constructed from both datasets showed that the planctomycetes form a coherent group and distinct lineage within the domain Bacteria. Analysis of 235 rRNA gene sequences of Verrucomicrobium spinosum, Prosthecobacter fusiformis and Prosthecobacter sp. strain FC-2 showed that these organisms cluster together, as was also shown here and previously by analysis of 16S rRNA gene sequences. The distinct phylogenetic position of the division Verrucomicrobia was also supported by analysis of the 235 rRNA gene sequences, and no statistically significant phylogenetic relationship between the division Verrucomicrobia and the planctomycetes was found. The analyses presented in this study also provide further evidence that the chlamydiae are no more related to members of the order Planctomycetales and the division Verrucomicrobia than they are to members of other bacterial lineages.
\end{abstract}

Keywords: 23S rRNA gene, phylogeny, Planctomycetales, Verrucomicrobia

\section{INTRODUCTION}

Comparative phylogenetic analyses using the largesubunit rRNA (Ludwig \& Schleifer, 1994), highly conserved proteins, such as elongation factors and ATPase subunits (Ludwig et al., 1993), and RNA polymerases (Pühler et al., 1989) generally correlate well with those performed with small-subunit rRNA data, supporting the phylogenetic distinctness of the

The GenBank accession numbers for the 23S rRNA gene sequences determined in this study are listed in Table 1.
Bacteria and Archaea and recovering similar phylogenies within the domain Bacteria. In particular, it has been demonstrated that the $23 \mathrm{~S}$ rRNA can serve as a phylogenetic marker and that the trees reconstructed from $16 \mathrm{~S}$ and $23 \mathrm{~S}$ rRNA sequence data are generally congruent (Leffers et al., 1987; Höpfl et al., 1989; Schleifer \& Ludwig, 1989; Ludwig et al., 1993; Ludwig \& Schleifer, 1994).

Analysis of 16S rRNA gene sequences has been shown to be a useful method for determining the extent of phylogenetic diversity within diverse groups of bacteria, including a group of planctomycete isolates 
(Ward et al., 1995; Griepenburg et al., 1999). However, in these studies, the addition of a large number of new planctomycete $16 \mathrm{~S}$ rRNA gene sequences did not allow a more accurate determination of the phylogenetic position of the planctomycete lineage in relation to other lineages within the domain Bacteria. Although the phylogenetic distinctness and coherence of the planctomycetes is evident in 16S rRNA gene sequence analyses, the relationship between the planctomycete lineage and other main lines, particularly members of the order Chlamydiales and the division Verrucomicrobia, remains unclear (Ward-Rainey et al., 1995). Given the recent expansion in size of the division Verrucomicrobia (which includes the singlespecies genus Verrucomicrobium spinosum, four strains of the genus Prosthecobacter and an ever-increasing number of environmental clone sequences; Hedlund et al., 1996), it is important to be able to elucidate the interphylum relationships.

To determine whether the use of an alternative molecular chronometer could resolve the uncertain branching points, sequence data were obtained for the genes encoding 23S rRNA $(r r l)$ from 13 planctomycete strains, V. spinosum, Prosthecobacter fusiformis and Prosthecobacter sp. strain FC-2. The 23S rRNA gene sequences were determined for the type strains of all of the validly described species. The phylogenies reconstructed from the sequence data for these molecules were compared with those obtained from 16S rRNA gene sequence analyses.

\section{METHODS}

Bacterial strains and culture conditions. Strains for which sequence data were obtained are listed in Table 1. The type strains of the validly described planctomycete species were obtained from the DSMZ (German Collection of Microorganisms and Cell Cultures, Braunschweig, Germany) and cultivated as described previously (Ward-Rainey et al., 1997). Planctomycete strains 139, 140, 449, 639, 658, 670 and $V$. spinosum DSM $4136^{\mathrm{T}}$ were provided by Heinz Schlesner (University of Kiel, Kiel, Germany). Prosthecobacter fusiformis DSM 8960 ${ }^{\mathrm{T}}$ and Prosthecobacter sp. strain FC-2 (ATCC 700199) were from the laboratory collection of James Staley (University of Washington, Seattle, WA, USA).

Isolation and purification of genomic DNA. Genomic DNA was isolated and purified as described previously (Rainey et al., 1996).

PCR-mediated amplification of 235 rRNA genes. Amplification of $23 \mathrm{~S}$ rRNA genes was performed using combinations of the PCR primers listed in Table 2. All other PCR parameters are as described for $16 \mathrm{~S}$ rRNA gene sequencing in Rainey et al. (1996).

Sequencing of 23S rRNA gene PCR products. The 23S rRNA gene PCR products were sequenced directly as described previously (Rainey et al., 1996), using the primers listed in Tables 2 and 3 .

\section{Sequence alignments}

$16 \mathrm{~S}$ rRNA gene sequence alignment. Comparative phylogenetic analyses using 16S rRNA gene sequences were performed using the following reference sequences (strains are indicated where available and EMBL accession numbers are provided in parentheses): Alcaligenes faecalis (M22508), Bacillus subtilis NCDO 1769 (X60646), Borrelia burgdorferi strain B31 (X57404), Bradyrhizobium japonicum LMG 6138 (D12781), Chlamydophila (formerly Chlamydia) psittaci strain 6 BC (M13769), Chlorobium limicola strain 8327 (M31769), Chloroflexus aurantiacus strain 1892 (M34116), Clostridium botulinum G (M59087), Escherichia coli (J01695), Flavobacterium odoratum (M58777), Gemmata obscuriglobus DSM 5831 ${ }^{\mathrm{T}}$ (AJ231191), Isosphaera pallida DSM 9630 ${ }^{\mathrm{T}}$ (AJ231195), Micrococcus luteus (M38242),

Table 1. Strains for which 235 rRNA gene sequence data were obtained, and the primer pairs used to amplify the 5 '-regions of the $23 \mathrm{~S}$ rRNA genes (other PCR primer combinations used were $255 \mathrm{f}-2053 \mathrm{r}$ and 1948f-25r)

\begin{tabular}{|c|c|c|c|}
\hline Strain & $\begin{array}{c}\text { Culture } \\
\text { collection no. }\end{array}$ & $\begin{array}{c}\text { Sequence } \\
\text { accession no. }\end{array}$ & Primer pair \\
\hline Planctomyces brasiliensis & DSM $5305^{\mathrm{T}}$ & AF245364 & 23Sfplan-803r \\
\hline Planctomyces limnophilus & DSM $3776^{\mathrm{T}}$ & AF245365 & 23Sfplan-803r \\
\hline Planctomyces maris & DSM $8797^{\mathrm{T}}$ & AF245366 & 23SfPlmar-803r \\
\hline Pirellula marina & DSM $3645^{\mathrm{T}}$ & AF245367 & 23Sfplan-803r \\
\hline Pirellula staleyi & DSM $6068^{\mathrm{T}}$ & AF245368 & 23Sfplan-803r \\
\hline Gemmata obscuriglobus & DSM $5831^{\mathrm{T}}$ & AF245369 & 23SfGemm-803r \\
\hline Isosphaera pallida & DSM $9630^{\mathrm{T}}$ & AF245370 & 1241 fplan-803r \\
\hline Planctomycete strain 139 & - & AF245371 & $23 \mathrm{Sf} 139-803 \mathrm{r}$ \\
\hline Planctomycete strain 140 & - & AF245372 & $23 \mathrm{Sf} 140-803 \mathrm{r}$ \\
\hline Planctomycete strain 449 & - & AF245373 & $23 \mathrm{Sf} 449-803 \mathrm{r}$ \\
\hline Planctomycete strain 639 & - & AF245374 & 23Sf639-803r \\
\hline Planctomycete strain 658 & - & AF245375 & $23 \mathrm{Sf} 658-803 \mathrm{r}$ \\
\hline Planctomycete strain 670 & - & AF245376 & $23 \mathrm{Sf} 670-803 \mathrm{r}$ \\
\hline Verrucomicrobium spinosum & DSM $4136^{\mathrm{T}}$ & AF245377 & 1248fplan-803r \\
\hline Prosthecobacter fusiformis & DSM $8960^{\mathrm{T}}$ & AF245378 & $1100 \mathrm{f}-803 \mathrm{r}$ \\
\hline Prosthecobacter sp. strain FC-2 & ATCC 700199 & AF245379 & $1100 \mathrm{f}-803 \mathrm{r}$ \\
\hline
\end{tabular}


Table 2. Primers tested for amplification of 235 rRNA gene

\begin{tabular}{|c|c|c|c|}
\hline $\begin{array}{l}\text { Primer } \\
\text { name }\end{array}$ & Primer sequence $\left(5^{\prime}-3^{\prime}\right)$ & Binding position* & Primer reference \\
\hline $1241 \mathrm{fplan}$ & CTG CAC ACG T(G/C)C TAC AAT G & $1223-1241(16 S)$ & This study \\
\hline 23Sfplan & AAT $(\mathrm{C} / \mathrm{A}) \mathrm{TA}(\mathrm{A} / \mathrm{T}) \mathrm{GT} \mathrm{G}(\mathrm{A} / \mathrm{G})(\mathrm{T} / \mathrm{C}) \mathrm{CAA}$ GC & $(-1) \dagger-16$ & This study \\
\hline 23SfPlmar & AAA TC(A/C) AAA CGG CTA AGC & $(-2)-16$ & This study \\
\hline 23SfGemm & GGG GAG TGC G(C/G)C CAA GC & $(-1)-16$ & This study \\
\hline 23SfIso & AAT CAG GGT GGT CAA GC & $(-1)-16$ & This study \\
\hline 23Sf139 & AAG TAG TGA TGG TCA A(A/G)C & $(-2)-16$ & This study \\
\hline 23Sf140 & GAT ATC GGT GGC CAA (G/A)C & $(-1)-16$ & This study \\
\hline $23 \mathrm{Sf} 449$ & CAA GAT ACC AAT GGT CAA G & $(-4)-15$ & This study \\
\hline 23Sf639 & TAG CAC AAA GTG GTC AAG & $(-3)-15$ & This study \\
\hline 23Sf658 & AGA ATT TAA ATG GTC AAG C & $(-3)-16$ & This study \\
\hline $23 \mathrm{Sf} 670$ & GAT CAA CGT GGT CAA GC & $(-1)-16$ & This study \\
\hline $241 \mathrm{r}$ & (GT)TT CGC TCG CC(A/G) CTA C & $241-256$ & Lane (1991) \\
\hline $255 f$ & AGT AG(C/T) GGC GAG CGA A & $241-255$ & Lane (1991) \\
\hline $559 \mathrm{r}$ & CAT T(A/C)T (A/G)CA AAA GG(C/T) ACG C & $559-577$ & This study, based on Lane (1991) \\
\hline $803 \mathrm{r}$ & TTC GG(A/G) GAG AAC (G/C)AG (A/C)TA & $803-822$ & $\begin{array}{l}\text { This study, based on } \\
\text { Ludwig et al. (1992) }\end{array}$ \\
\hline $1091 \mathrm{r}$ & $\operatorname{AGT}(\mathrm{A} / \mathrm{G}) \mathrm{AG} \mathrm{CT}(\mathrm{A} / \mathrm{G}) \mathrm{TTA}$ CGC & $1091-1105$ & This study, based on Lane (1991) \\
\hline $1358 \mathrm{r}$ & TAC GC(C/T) T(G/T)T C(A/G)G CCT C & $1358-1373$ & This study \\
\hline $1685 \mathrm{r}$ & CCT T(A/C)T C(C/G)C GAA (C/G)TT ACG G & $1685-1703$ & $\begin{array}{l}\text { This study, based on } \\
\text { Ludwig et al. (1992) }\end{array}$ \\
\hline $1948 f$ & GTA GCG AA(A/G) TTC CTT GTC G & $1930-1948$ & $\begin{array}{l}\text { This study, based on } \\
\text { Ludwig et al. (1992) }\end{array}$ \\
\hline $2053 \mathrm{r}$ & $\mathrm{CA}(\mathrm{C} / \mathrm{T})(\mathrm{A} / \mathrm{G}) \mathrm{GG}$ GTC TTT C $(\mathrm{C} / \mathrm{T}) \mathrm{G}$ TC & $2053-2069$ & This study, based on Lane (1991) \\
\hline $2498 \mathrm{r}$ & GAG $(\mathrm{C} / \mathrm{T}) \mathrm{CG}$ ACA TCG AGG & $2498-2512$ & Lane (1991) \\
\hline $2603 f$ & $\mathrm{~A}(\mathrm{~A} / \mathrm{G}) \mathrm{A}(\mathrm{A} / \mathrm{C}) \mathrm{CG}$ TCG TGA GAC AG & $2587-2603$ & $\begin{array}{l}\text { This study, based on } \\
\text { van Camp et al. (1993) }\end{array}$ \\
\hline $25 \mathrm{r}$ & $(\mathrm{C} / \mathrm{G})(\mathrm{C} / \mathrm{T}) \mathrm{G}$ TTC GG(A/G) A(A/T)G GGA & $25-49(5 \mathrm{~S})$ & Ludwig et al. (1992) \\
\hline
\end{tabular}

* Escherichia coli nomenclature (Brosius et al., 1978, 1980).

$\dagger$ Negative numbers denote positions upstream of E. coli position 1.

Table 3. Additional primers used to sequence the 235 rRNA gene

\begin{tabular}{|c|c|c|c|}
\hline $\begin{array}{l}\text { Primer } \\
\text { name }\end{array}$ & Primer sequence $\left(5^{\prime}-3^{\prime}\right)$ & $\begin{array}{l}\text { Binding } \\
\text { position* }\end{array}$ & Primer reference \\
\hline 559rmod & CAT T(A/T)T (A/G)CA AAA GGC A(G/T/C)G C & $559-577$ & This study, based on Lane (1991) \\
\hline 559rplan & CAT TAT $(\mathrm{G} / \mathrm{T}) \mathrm{CA}$ A(T/A)A GGC AC(G/A) C & $559-577$ & This study, based on Lane (1991) \\
\hline 577 fplan & GCG TGC C(T/A/T) TTG (C/A)AT AAT G & $559-577$ & This study, based on Lane (1991) \\
\hline $975 \mathrm{r}$ & TCT GGG $(\mathrm{T} / \mathrm{C}) \mathrm{TG} \mathrm{TT}(\mathrm{T} / \mathrm{C}) \mathrm{CCC} \mathrm{T}$ & $975-990$ & Ludwig et al. (1992) \\
\hline $990 \mathrm{f}$ & AGG G(A/G)A ACA (A/G)CC CAG A & $975-990$ & This study, based on Ludwig et al. (1992) \\
\hline $1200 \mathrm{f}$ & GGT AG(A/G) (A/G)GA GCG TTC & $1186-1200$ & This study \\
\hline $1373 f$ & GAG GCC GA(A/C) A(A/G)G CGT A & $1358-1373$ & This study \\
\hline $1608 \mathrm{r}$ & $\mathrm{C}(\mathrm{C} / \mathrm{T}) \mathrm{A}$ CCT GTG $(\mathrm{A} / \mathrm{T}) \mathrm{C}(\mathrm{A} / \mathrm{G}) \mathrm{GTT} \mathrm{T}$ & $1608-1623$ & This study, based on Lane (1991) \\
\hline $2069 f$ & GAC (A/G)GA AAG ACC CC(A/G) TG & $2053-2069$ & This study, based on Lane (1991) \\
\hline $2744 \mathrm{r}$ & CTT AGA TGC (C/T)TT CAG C & $2744-2759$ & Ludwig et al. (1992) \\
\hline 2744rplan & CTT A(T/G)A TGC (C/T)TT CAG C & $2744-2759$ & This study, based on Ludwig et al. (1992) \\
\hline
\end{tabular}

*E. coli nomenclature (Brosius et al., 1980).

Nannocystis exedens strain Na e1 (M94279), Pirellula marina IFAM 1313 (X62912), Pirellula staleyi DSM 6068 (AJ231183), Planctomyces brasiliensis DSM 5305
(AJ231190), Planctomyces limnophilus IFAM 1008 (X62911), Planctomyces maris DSM 8797' (AJ231184), Prosthecobacter fusiformis DSM 8960 ${ }^{\mathrm{T}}$ (U60015), Prostheco- 
bacter sp. strain FC-2 ATCC 700199 (U60013), Staphylococcus aureus ATCC 12600 (X68417), planctomycete strains 139 (X81945), 140 (X81939), 449 (AJ231177), 639 (X81950), 658 (X81954) and 670 (X81948), and Streptomyces griseus ATCC 10137 (X55435), Thermus thermophilus strain HB8 (X07998), Thermotoga maritima strain MSB8 (M21774) and Verrucomicrobium spinosum DSM 4136 (X90515). Sequences were aligned manually using the ae2 sequence editor (Maidak et al., 1999).

235 rRNA gene sequence alignment. 23S rRNA gene sequences were aligned using the alignment facility of the ARB package (W. Ludwig \& O. Strunk, http://www.biol.chemie. tu-muenchen.de/pub/ARB/). The reference sequences used in phylogenetic analyses included the following (strains are indicated where available and sequence accession numbers are provided in parentheses): A faecalis DSM 30030 ${ }^{\mathrm{T}}$ (X87282), Bacillus subtilis (D11460), Borrelia burgdorferi (M88330), Bradyrhizobium japonicum DSM 30131 (X71840), Chlamydia sp. strain BN9 (Y07555), Chlorobium limicola (M62805), Clostridium botulinum NCTC 7272 (X65602), E. coli (J01965), F. odoratum (M62807), M. luteus DSM 20030 (X06484), N. exedens DSM 71 ${ }^{\mathrm{T}}$ (X87286), Staphylococcus aureus ATCC 12600 (X68425), Streptomyces griseus (M76388), Thermus thermophilus HB8 (X12612) and Thermotoga maritima (M67498).

Phylogenetic analyses. Phylogenetic analyses of $16 \mathrm{~S}$ rRNA and $23 \mathrm{~S}$ rRNA gene sequences were performed using the programs DNADIST, DNAPARS, NEIGHBOR and CONSENSE contained in the PHYLIP package (Felsenstein, 1993). Bootstrap analysis was performed using SEQBOOT (Felsenstein, 1993) and 1000 bootstrapped datasets.

The dendrograms presented here were reconstructed by the neighbour-joining method (Saitou \& Nei, 1987) from distance matrices (Jukes \& Cantor, 1969).

\section{RESULTS AND DISCUSSION}

\section{S rRNA gene sequence analyses}

Phylogenetic analyses of $16 \mathrm{~S}$ rRNA gene sequences were performed on a dataset consisting of 1145 nucleotide positions ( $E$. coli positions 40-1470). The 16S rRNA gene sequence analysis (Fig. 1a) demonstrated the phylogenetic distinctness of the planctomycete lineage. Members of the order Planctomycetales shared only $68 \cdot 1-76 \cdot 4 \% \quad 16 \mathrm{~S}$ rRNA gene sequence similarity to members of other lineages, while the intragroup similarity values ranged from $77 \cdot 2$ to $92 \cdot 0 \%$. The distinct phylogenetic position of, and phylogenetic depth within, the planctomycete lineage has been shown previously (Stackebrandt et al., 1984, 1986a, b; Liesack et al., 1992; Ward et al., 1995; Griepenburg et al., 1999). The phylogenetic coherence of the members of the order Planctomycetales was indicated by the recovery of this cluster in all trees generated from the bootstrapped dataset (Fig. 1a).

The fimbriate, prosthecate bacterium $V$. spinosum and the two strains of the genus Prosthecobacter formed a distinct phylogenetic lineage (Fig. 1a), as has been shown previously (Ward-Rainey et al., 1995; Hedlund et al., 1996), and clustered together in $100 \%$ of trees generated by bootstrap analysis. The intragroup $16 \mathrm{~S}$
rRNA gene sequence similarities ranged from 92.8 to $96.6 \%$. These three members of the division Verrucomicrobia showed low levels of $16 \mathrm{~S}$ rRNA gene sequence similarity to members of other lineages $(69 \cdot 3-77 \cdot 9 \%)$. In this dendrogram there is no specific relationship between the planctomycete lineage and those of the chlamydiae and the division Verrucomicrobia. A common branching point is shared by the division Verrucomicrobia and the chlamydiae, but is not supported by bootstrap analysis (66\%). Neighbour-joining analysis using the maximum-likelihood correction recovered the same tree topology as was found using the Jukes \& Cantor correction, while maximum-parsimony did not recover any relationship between the planctomycetes, chlamydiae and Verrucomicrobia (data not shown). The $16 \mathrm{~S}$ rRNA gene sequence similarity values between the Verrucomicrobia, the planctomycetes and the chlamydiae are not any higher than those between the Verrucomicrobia and members of other lineages.

\section{S rRNA gene sequence analyses}

PCR amplification. The PCR primers used in this study included those from previous 23S rRNA gene sequence-based phylogenetic studies (Lane, 1991; Ludwig \& Schleifer, 1994). In some cases, the primers were modified on the basis of the 23S rRNA gene sequence of Pirellula marina (Liesack et al., 1988).

The 23S rRNA gene could be amplified from all strains in three overlapping PCR reactions (Table 1 ). The $5^{\prime}-$ region of the $23 \mathrm{~S}$ rRNA gene was amplified successfully from $I$. pallida and $V$. spinosum using the primer combinations 1230fplan (binding to the $16 \mathrm{~S}$ rRNA gene) and $803 \mathrm{r}$ (binding to the 23S rRNA gene). The 5' 23S rRNA gene regions of Prosthecobacter fusiformis and Prosthecobacter sp. strain FC-2 were amplified using primers 1100 f and 803r. However, this could not be achieved for the other strains investigated, as the 23S rRNA gene was found not to be linked to the $16 \mathrm{~S}$ rRNA gene, making it impossible to use the $3^{\prime}-$ end of the $16 \mathrm{~S}$ rRNA gene as a target site for a PCR primer. Unlinked rRNA genes have been previously reported for Pirellula marina (Liesack \& Stackebrandt, 1989), Planctomyces limnophilus and G. obscuriglobus (Menke et al., 1991). The results of this study suggest that this arrangement is the most common one in planctomycetes, with $I$. pallida providing an exception to the rule. Linked $16 \mathrm{~S}$ and $23 \mathrm{~S}$ rRNA genes have been demonstrated by the PCR in strain 657 (data not shown), which is phylogenetically related to I. pallida (Ward et al., 1995). The 16S and 23S rRNA genes of $V$. spinosum had been shown previously, by ribotyping, to be linked together (Menke et al., 1991).

To obtain sequence data from the $5^{\prime}$-end of the $23 \mathrm{~S}$ rRNA gene for the remainder of the strains, an alternative strategy was employed. Using the sequence data from the $3^{\prime}$-end of the molecule as a template, the processing stem that separates the $23 \mathrm{~S}$ rRNA gene 
(a)

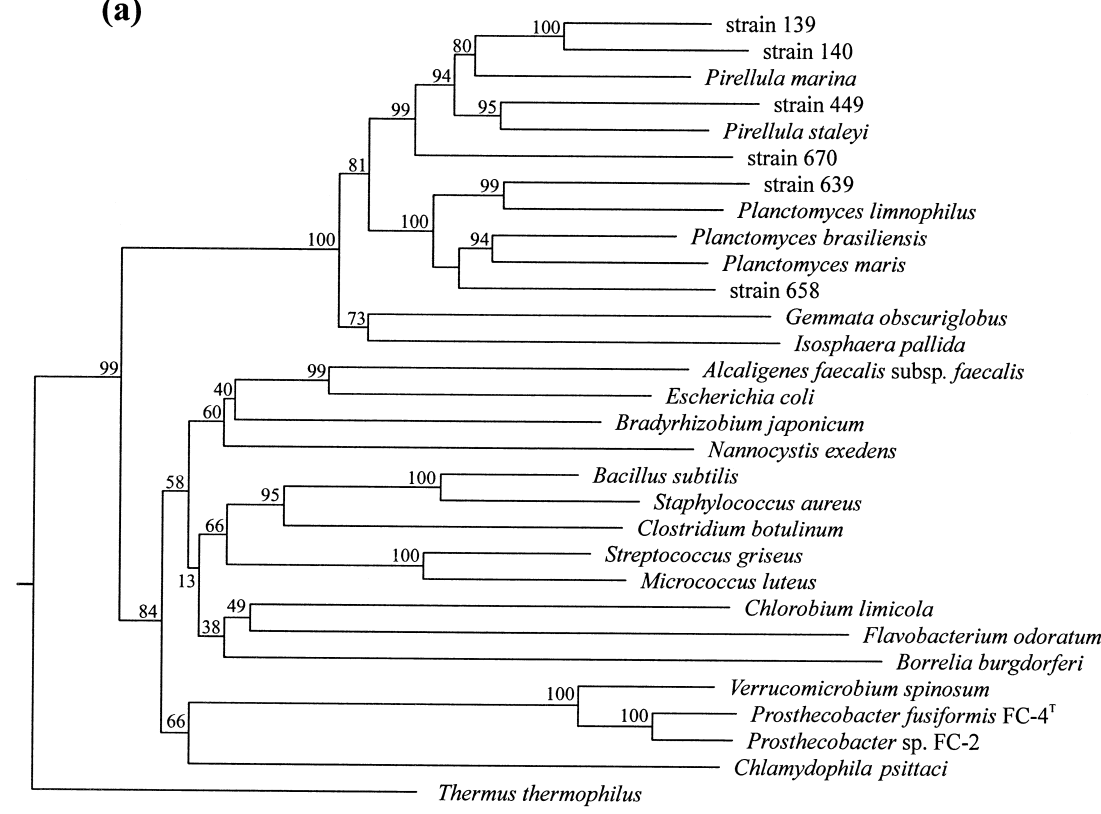

$10.0 \%$ (b)

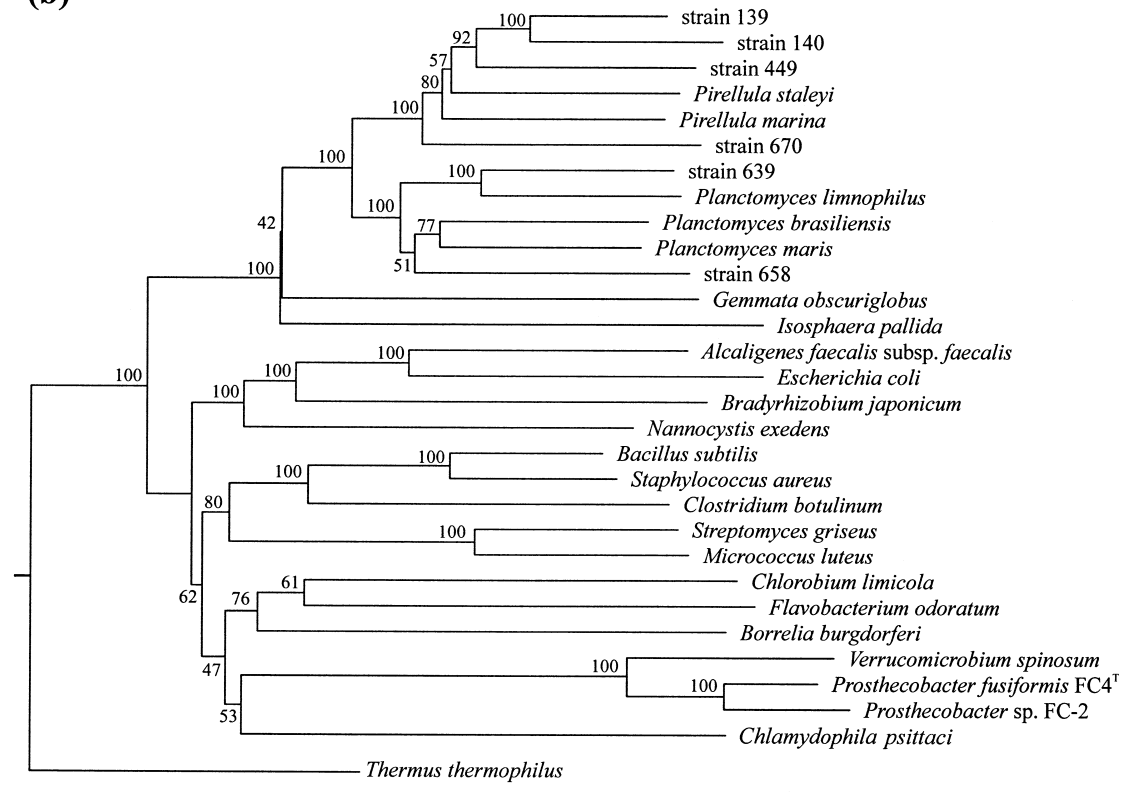

$10.0 \%$

Fig. 1. (a) $16 \mathrm{~S}$ rRNA gene and (b) $23 \mathrm{~S}$ rRNA gene sequence-based phylogenetic dendrograms, indicating the phylogenetic relationships between members of the order Planctomycetales, the division Verrucomicrobia and representatives of the main lineages within the domain Bacteria. Roots were determined by using the $16 \mathrm{~S}$ rRNA or $23 \mathrm{~S}$ rRNA gene sequences of Thermotoga maritima as outgroups. Bars, 10 inferred nucleotide substitutions per 100 nucleotides (as determined by measuring the length of the horizontal lines joining any two organisms). Numbers at nodes refer to bootstrap values. 


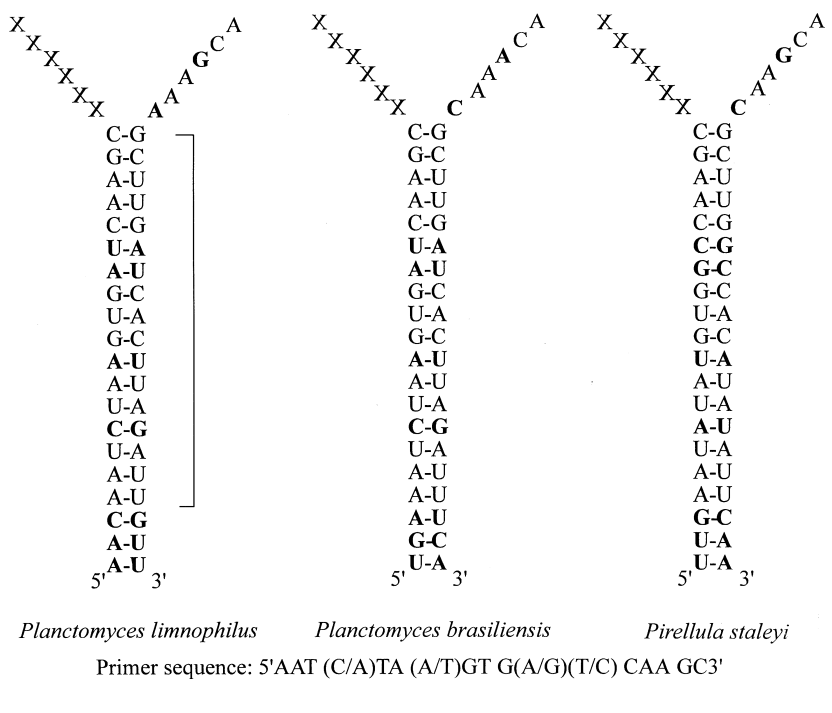

Fig. 2. Schematic illustration of the strategy used to design $P C R$ primers to amplify the 5'-region of the 23S rRNA gene of planctomycete strains. The stems formed by the base pairing of the 5'- and 3'-termini of the 235 rRNA are shown for three strains. The right-hand side of each stem represents the $3^{\prime} 235$ rRNA gene sequence determined empirically. The left-hand side of each stem represents the deduced sequence of the $5^{\prime}$ terminus. Variable residues are depicted in bold type. The region used for the design of the PCR primers is bracketed and the sequence of the PCR primer designed for these three strains is provided at the bottom.

from flanking DNA was reconstructed (Fig. 2). Perfect Watson-Crick base-pairing in this region was assumed and the result was used to design a PCR primer that could be used for the amplification of the $5^{\prime}$-region of the gene. The high sequence variability in this region made it necessary to design nine different primers (Table 2). With the exception of strains 139, 140 and 449 , the $5^{\prime}$-region of the 23S rRNA gene was amplified successfully using these primers and the PCR conditions described previously. In the case of strains 139, 140 and 449, the PCR reaction consistently produced additional non-specific bands even when highly stringent PCR conditions were used. This problem was circumvented by excising the target band from a preparative agarose gel of the PCR product, purifying the DNA and using it as template for another round of PCR. In this way, a PCR product of the correct size was obtained.

The $3^{\prime}$-end of the 23S rRNA gene proved much easier to obtain, as the 5S rRNA gene was found to be linked to the 23S rRNA in all strains investigated. Thus the 3'end of the 23S rRNA gene could be amplified using a primer binding to the 5S rRNA gene.

Sequence analyses. Complete $23 \mathrm{~S}$ rRNA gene sequences, from position 1 to position 2904 (E. coli nomenclature; Brosius et al., 1980) were obtained for 13 planctomycete strains, V. spinosum and the two Prosthecobacter strains. To obtain the sequence data, many of the previously described 23S rRNA gene-sequencing primers had to be modified (Table 3 ) because of mismatches between the primers and the new 23S rRNA gene sequences.

The 23S rRNA gene sequence dataset used for analyses contained all of the 23S rRNA gene sequences determined in this study and several reference sequences. Comparison of complete 23S rRNA gene sequences was not possible because of the inclusion of reference sequences lacking the 3'-terminus of the molecule. Regions of ambiguous alignment were excluded from the analysis, resulting in a dataset comprising 2550 nucleotide positions (E. coli positions 1-136, 161-268, 286-362, 371-542, 552-651, 655-1163, 1188-1414, 1420-1466, 1546-1577, 1587-1712, 1750-2204 and 2208-2768).

The 23S rRNA gene sequence data were used to reconstruct phylogenetic dendrograms (Fig. 1b) showing the relationships of members of the order Planctomycetales and the division Verrucomicrobia with respect to representatives of the major lines of descent within the domain Bacteria. Fig. 1b, which was generated by the neighbour-joining method, shows the planctomycetes and the division Verrucomicrobia to be unrelated to members of any other lineages within the domain Bacteria, as has been shown previously by $23 \mathrm{~S}$ rRNA gene sequence analysis of Pirellula marina (Ludwig \& Schleifer, 1994). Comparison of a larger number of planctomycete 23S rRNA gene sequences confirmed the isolated phylogenetic position suggested by the topology of the tree presented in Ludwig \& Schleifer (1994). The phylogenetic coherence of the planctomycete lineage was also demonstrated by a $100 \%$ bootstrap value for the node representing the common ancestor of this group.

The 23S rRNA gene sequence similarity between the planctomycetes and members of other lineages within the domain Bacteria ranged from 68.0 to $76.2 \%$, whereas the intragroup similarities were between 75.8 and $91.2 \%$. Members of the division Verrucomicrobia shared $68 \cdot 0-74 \cdot 0 \%$ 23S rRNA gene sequence similarity with members of other lineages and were shown to be a phylogenetically coherent group recovered in $100 \%$ of trees generated by bootstrap analysis. The Verrucomicrobia intragroup similarity values ranged from $89 \cdot 3$ to $94 \cdot 2 \%$. The $23 \mathrm{~S}$ rRNA gene sequence similarity values are in very close agreement with the similarity values obtained by comparison of $16 \mathrm{~S}$ rRNA gene sequences (see above). On the basis of $23 \mathrm{~S}$ rRNA gene sequence analyses, no relationship between the planctomycetes, the division Verrucomicrobia and the chlamydiae was observed (Fig. 1b).

Comparison of the intra phylum relationships within the order Planctomycetales revealed by $16 \mathrm{~S}$ and $23 \mathrm{~S}$ rRNA gene sequence analyses (Fig. 1a, b) shows some similarities. A relationship between $G$. obscuriglobus and I. pallida is observed in the $16 \mathrm{~S}$ rRNA gene sequence-based tree (Fig. 1a), but is not supported by bootstrap analysis, as has been reported previously in a 16S rRNA gene sequence-based phylogenetic study of planctomycetes (Liesack et al., 1992). The instability 
of the Gemmata-Isosphaera branching point is also demonstrated by a bootstrap value of $42 \%$ for this node in the 23S rRNA gene sequence-based tree.

Analysis of 23S rRNA gene sequences showed the same relationship between members of the genus Planctomyces and strains 639 and 658 (Fig. 1b) as that seen with 16S rRNA gene sequence analysis (Fig. 1a), and the Planctomyces cluster is recovered in all trees in both cases. Some rearrangements in branching order between the $16 \mathrm{~S}$ and $23 \mathrm{~S}$ rRNA gene trees are seen within the group containing members of the genus Pirellula and the strains 139, 140 and 449. Examination of the phylogenetic relationships of all members of this group (Ward et al., 1995; Griepenburg et al., 1999) showed that the branching points within the cluster are rather unstable, so some discrepancies in internal structure when $16 \mathrm{~S}$ and $23 \mathrm{~S}$ rRNA genes are used is not surprising. This cluster is recovered in $94 \%$ of trees generated using 16S rRNA gene sequences but in only $80 \%$ of $23 \mathrm{~S}$ rRNA gene sequence-based trees (Fig. 1). The group containing Planctomyces and Pirellula is supported by a $100 \%$ bootstrap value for $23 \mathrm{~S}$ rRNA gene sequence analysis (Fig. 1b) but is recovered in only $81 \%$ of $16 \mathrm{~S}$ rRNA gene sequence-based trees (Fig. 1a).

Phylogenetic analyses of the 23S rRNA gene sequence dataset obtained using the neighbour-joining method with the maximum-likelihood correction (Felsenstein, 1981) produced the same tree topology as that found using the correction of Jukes \& Cantor (1969) (data not shown). Phylogenetic analysis by maximum parsimony also produced the same tree as that obtained by neighbour-joining, except that members of the division Verrucomicrobia were found to group with the planctomycetes, whereas the low- and high-G+C Gram-positive bacteria did not cluster together.

Deletions in the 23S rRNA genes of some planctomycetes and $\boldsymbol{V}$. spinosum. The $23 \mathrm{~S}$ rRNA genes of Planctomyces brasiliensis, Planctomyces limnophilus, G. obscuriglobus, V. spinosum, Prosthecobacter fusiformis, Prosthecobacter sp. strain FC-2, strain 639 and strain 670 were shown to carry a deletion of approximately 50 nucleotides in domain III, which encompasses helix 58. Deletion of helix 58 has been reported only in members of the $\alpha$-subclass of the Proteobacteria and has been suggested to be a signature for members of this group (Ludwig \& Schleifer, 1994). The presence of helix 58 in some planctomycete strains indicates that this signature is not exclusive to the $\alpha$-Proteobacteria. The fact that the deletion does not occur in all planctomycete strains means that it cannot be considered as a signature for the planctomycete lineage and probably indicates that its phylogenetic meaning is restricted to lower taxonomic levels.

\section{Conclusions}

Almost complete 23S rRNA gene sequences were obtained from 13 planctomycete strains, V. spinosum, Prosthecobacter fusiformis and Prosthecobacter sp. strain FC-2. The modified 23S rRNA gene PCR primer set provides a useful resource for future $23 \mathrm{~S}$ rRNA gene sequence analysis of additional planctomycete strains and members of the division Verrucomicrobia.

The phylogenetic position of the planctomycetes and members of the division Verrucomicrobia was determined using 16S rRNA and 23S rRNA gene sequences. Comparative phylogenetic analyses were performed using $16 \mathrm{~S}$ and $23 \mathrm{~S}$ rRNA gene reference sequences from the same species. Phylogenetic analyses using both genes showed that the planctomycete strains investigated form a phylogenetically distinct lineage within the domain Bacteria. These analyses using multiple planctomycete sequences, including members of as yet undescribed taxa confirmed the results previously obtained with the $23 \mathrm{~S}$ rRNA gene sequence of the single planctomycete species Pirellula marina (Liesack et al., 1988; Ludwig \& Schleifer, 1994). Analysis of multiple planctomycete sequences confirmed the phylogenetic coherence of the planctomycete lineage, which was previously suggested by the results of $16 \mathrm{~S}$ rRNA gene sequence analyses (Stackebrandt et al., 1986a, b; Liesack et al., 1992; Ward et al., 1995; Griepenburg et al., 1999). The phylogenetic distinctness, coherence and depth of the planctomycete lineage were evident from the results of three different methods of phylogenetic analysis and were supported by bootstrap analyses.

The phylogenetic distinctness of the division Verrucomicrobia was confirmed in this study by analysis of complete 16S and 23S rRNA gene sequences and was observed in the dendrograms produced from all methods of analysis. However, the phylogenetic position of members of the division Verrucomicrobia in relation to other members of the domain Bacteria was shown to depend on the numbers of planctomycete sequences included in the analyses and the method of analysis chosen. The branching-point instability of the Verrucomicrobia lineage is reflected in the low level of statistical significance assigned to any grouping involving these taxa.

In conclusion, phylogenetic analyses using two different molecular chronometers have confirmed the phylogenetic distinctness of the planctomycete and Verrucomicrobia lineages and have indicated that there is no statistically significant relationship between the members of these two lineages and the chlamydiae.

\section{REFERENCES}

Brosius, J., Palmer, M. L., Kennedy, J. P. \& Noller, H. P. (1978). Complete nucleotide sequence of a $16 \mathrm{~S}$ ribosomal RNA gene from Escherichia coli, Proc Natl Acad Sci U S A 75, 4801-4805.

Brosius, J., Dull, T. J. \& Noller, H. P. (1980). Complete nucleotide sequence of a $23 \mathrm{~S}$ ribosomal RNA gene from Escherichia coli, Proc Natl Acad Sci U S A 77, 201-204.

van Camp, G., Chapelle, S. \& De Wachter, R. (1993). Amplification and sequencing of variable regions in bacterial $23 \mathrm{~S}$ ribosomal RNA genes with conserved primer sequences, Curr Microbiol 27, 147-151. 
Felsenstein, J. (1981). Evolutionary trees from DNA sequences: a maximum likelihood approach, J Mol Evol 17, 368-376.

Felsenstein, J. (1993). PHYLIP (phylogenetic inference package) version 3.5.1. Seattle: University of Washington.

Griepenburg, U., Ward-Rainey, N., Mohamed, S., Schlesner, H., Marxsen, H., Rainey, F. A., Stackebrandt, E. \& Auling, G. (1999). Phylogenetic diversity, polyamine pattern and DNA base composition of members of the order Planctomycetales, Int $J$ Syst Bacteriol 49, 689-696.

Hedlund, B. P., Gosink, J. L. \& Staley, J. T. (1996). Phylogeny of Prosthecobacter, the fusiform caulobacters: members of a recently discovered division of the Bacteria, Int J Syst Bacteriol 46, 960-966.

Höpfl, P., Ludwig, W., Schleifer, K.-H. \& Larsen, N. (1989). The 23S ribosomal RNA higher-order structure of Pseudomonas cepacia and other prokaryotes, Eur J Biochem 185, 355-364.

Jukes, T. H. \& Cantor, C. R. (1969). Evolution of protein molecules. In Mammalian Protein Metabolism, pp. 21-132. Edited by H. N. Munro. New York: Academic Press.

Lane, D. J. (1991). 16S/23S rRNA sequencing. In Nucleic Acid Techniques in Bacterial Systematics, pp. 115-175. Edited by E. Stackebrandt \& M. Goodfellow. New York: Wiley.

Leffers, H., Kjems, J., Laust, O., Larsen, N. \& Garret, R. A. (1987). Evolutionary relationships amongst archaebacteria. A comparative study of $23 \mathrm{~S}$ rRNAs of a sulphur-dependent extreme thermophile, an extreme halophile and a thermophilic methanogen, $J$ Mol Biol 195, 43-61.

Liesack, W. \& Stackebrandt, E. (1989). Evidence for unlinked $r r n$ operons in the planctomycete Pirellula marina, J Bacteriol $\mathbf{1 7 1}$, $5025-5030$

Liesack, W., Höpfl, P. \& Stackebrandt, E. (1988). Complete nucleotide sequence of a $23 \mathrm{~S}$ ribosomal RNA gene from Pirellula marina, Nucleic Acids Res 16, 5194.

Liesack, W., Söller, R., Stewart, T., Haas, H., Giovannoni, S. \& Stackebrandt, E. (1992). The influence of tachytelically (rapidly) evolving sequences on the topology of phylogenetic trees - intrafamily relationships and the phylogenetic position of the Planctomycetaceae as revealed by comparative analysis of $16 \mathrm{~S}$ ribosomal RNA sequences, Syst Appl Microbiol 15, $357-362$

Ludwig, W. \& Schleifer, K.-H. (1994). Bacterial phylogeny based on $16 \mathrm{~S}$ and 23S rRNA sequence analysis, FEMS Microbiol Rev 15, 155-173.

Ludwig, W., \& Strunk, O. (1996). ARB: a software environment for sequence data. http://www.mikro.biologie.tu-muenchen. $\mathrm{de} / \mathrm{pub} / \mathrm{ARB} /$ documentation/arb.ps.

Ludwig W., Kirchhof, G., Klugbauer, N. \& 13 other authors (1992). Complete 23S ribosomal RNA sequences of Grampositive bacteria with a low DNA G+C content. Syst Appl Microbiol 15, 487-501.
Ludwig, W., Neumaier, J., Klugbauer, N. \& 9 other authors (1993). Phylogenetic relationships of Bacteria based on comparative sequence analysis of elongation factor Tu and ATP-synthase $\beta$ subunit genes. Antonie Leeuwenhoek 64, 285-305.

Maidak, B. L., Cole, J. R., Parker, C. T., Jr \& 11 other authors (1999). A new version of the RDP (Ribosomal Database Project). Nucleic Acids Res 27, 171-173.

Menke, M. A. O. H., Liesack, W. \& Stackebrandt, E. (1991). Ribotyping of $16 \mathrm{~S}$ and $23 \mathrm{~S}$ rRNA genes and organization of $\mathrm{rrn}$ operons in members of the bacterial genera Gemmata, Planctomyces, Thermotoga, Thermus and Verrucomicrobium, Arch Microbiol 155, 263-271.

Pühler, G., Leffers, H., Gropp, F., Palm, P., Klenk, H. P., Lottspeich, F., Garrett, R. A. \& Zillig, W. (1989). Archaebacterial DNAdependent RNA polymerases testify to the evolution of the eukaryotic nuclear genome, Proc Natl Acad Sci U $S$ A 86, 4569-4573.

Rainey, F. A., Ward-Rainey, N., Kroppenstedt, R. M. \& Stackebrandt, E. (1996). The genus Nocardiopsis represents a phylogenetically coherent taxon and a distinct actinomycete lineage: proposal of Nocardiopsaceae fam. nov, Int $J$ Syst Bacteriol 46, 1088-1092.

Saitou, N. \& Nei, M. (1987). The neighbor-joining method: a new method for reconstructing phylogenetic trees, Mol Biol Evol 4, 406-425.

Schleifer, K. H. \& Ludwig, W. (1989). Phylogenetic relationships among bacteria. In The Hierarchy of Life, pp. 103-117. Edited by B. Fernholm, K. Bremer \& H. Jörnwall. Amsterdam: Elsevier.

Stackebrandt, E., Ludwig, W., Schubert, W., Klink, F., Schlesner, H., Roggentin, T. \& Hirsch, P. (1984). Molecular genetic evidence for early evolutionary origin of budding peptidoglycan-less eubacteria, Nature 307, 735-737.

Stackebrandt, E., Fischer, A., Hirsch, P., Roggentin, T. \& Schlesner, H. (1986a). The phylogeny of an ancient group of budding peptidoglycan-less eubacteria: the genera Planctomyces and Pirella, Endocyt Cell Res 3, 29-40.

Stackebrandt, E., Wehmeyer, U. \& Liesack, W. (1986b). 16S ribosomal RNA- and cell wall analysis of Gemmata obscuriglobus, a new member of the order Planctomycetales, FEMS Microbiol Lett 37, 289-292.

Ward, N., Rainey, F. A., Stackebrandt, E. \& Schlesner, H. (1995). Unraveling the extent of diversity within the order Planctomycetales, Appl Environ Microbiol 61, 2270-2275.

Ward-Rainey, N., Rainey, F. A., Schlesner, H. \& Stackebrandt, E. (1995). Assignment of hitherto unidentified 16S rDNA species to a main line of descent within the domain Bacteria, Microbiology 141, 3247-3250.

Ward-Rainey, N., Rainey, F. A. \& Stackebrandt, E. (1997). The presence of a dnaK (HSP70) multigene family in members of the orders Planctomycetales and Verrucomicrobiales, J Bacteriol 179, 6360-6366. 